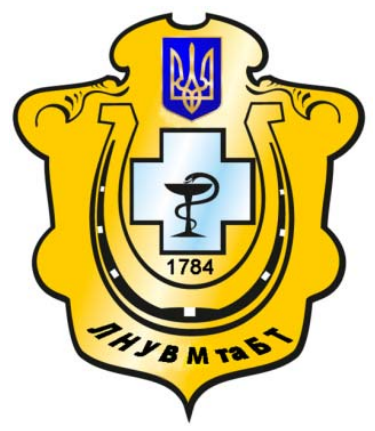

Науковий вісник Львівського національного університету ветеринарної медицини та біотехнологій імені С.3. Гжицького

Scientific Messenger of Lviv National University of Veterinary Medicine and Biotechnologies named after S.Z. Gzhytskyj

doi:10.15421/nvlvet7149

ISSN 2413-5550 print

ISSN 2518-1327 online

$\underline{\text { http://nvlvet.com.ua/ }}$

УДК 619:618:619:616.07:636.2

\title{
Hysteroscopic investigation of dairy cows uterus with subclinical endometritis
}

\author{
T.P. Basarab, V.Y. Stefanyk \\ basarabtaras@gmail.com \\ Lviv National University of Veterinary Medicine and Biotechnologies named after S.Z. Gzhytskyi, \\ Pekarska Str., 50, Lviv, 79010, Ukraine
}

\begin{abstract}
During the postpartum period among the dairy cattle there are cases of bacteriological infection of the uterus tissues. This process occurs in over $90 \%$ of the herd. If the animal wasn't provided with early effective treatment, acute inflammation becomes a chronic disease. After analyzing published data, it was concluded that hysteroscopic studies are not described enough. For this study $5(n=5)$ cows of Ukrainian black and white breed, aged 4 to 6 years were selected, which had not shown estrus for over 25 days. Diagnosis was reached by hysteroscopy of uterus. Analysis of the data has proved that area size of bright red color of uterus with subclinical endometritis was $-57.6 \pm 5.2 \%$, whereas after the treatment with «Metrodek» it decreased by more than 7 times $-7.3 \pm$ $1.6 \%(p<0.001)$; area of exudate in the uterus with subclinical endmometritis was $-59.3 \pm 6.5 \%$, whereas after the treatment with «Metrodek» decreased about 11 times $-5.4 \pm 1.1 \%(p<0,001)$.

Key words: cow, uterus, hysteroscopy, postpartum period, endometritis, subclinical endometritis, infertility, function of reproduction.
\end{abstract}

\section{Гістероскопічне дослідження матки корів при субклінічному ендометриті}

\author{
Т.П. Басараб, В.Ю. Стефаник \\ basarabtaras@gmail.com
}

Львівський національний університет ветеринарної медицини та біотехнологій імені С.3. Гжицького, вул. Пекарська, 50, м. Львів, 79010, Україна

\begin{abstract}
Під час перебігу післяродового періоду, у корів зустрічаються випадки бактеріологічного інфікування тканин матки, цей процес спостерігається, більш ніж у 90\% тварин. Якщо тварині не було надане своєчасне, ефективне лікування, тоді гострий запальний проиес переходить у хронічне захворювання. Аналізуючи літературні дані, ми прийшли до висновку, що гістероскопічне дослідження у корів є недостатньо описане. Для постановки дослідження було відібрано $5(n=5)$ корів української чорно-рябої породи, віком від 4 до 6 років, у яких не проявлялася стадія збудження понад 25 діб. Для постановки діагнозу проводили гістероскопію матки у корів. Аналіз отриманих візуальних результатів засвідчив, щуо площза яскравочервоного забарвлення стінок матки при субклінічному ендометриті становила - 57,6 \pm 5,2\%, після лікування препаратом «Метродек» змениилась більш ніж у 7 разів і становила - 7,3 $\pm 1,6 \%(p<0,001)$; плоша нашарування ексудату на стінки матки при субклінічному ендометриті становила - 59,3 \pm 6,5\%, після лікування препаратом «Метродек» зменшилась у 11 разів і становила $-5,4 \pm 1,1 \%(p<0,001)$.
\end{abstract}

Ключові слова: корова, матка, гістероскопія, післяродовий період, ендометрит, субклінічний ендометрит, неплідність, функиія відтворення

\section{Гистероскопическое исследование матки коров за субкленического ендометрита}

\author{
Т.П. Басараб, В.Ю. Стефаник \\ basarabtaras@gmail.com
}

\section{Citation:}

Basarab, T.P., Stefanyk, V.Y. (2016). Hysteroscopic investigation of dairy cows uterus with subclinical endometritis. Scientific Messenger LNUVMBT named after S.Z. Gzhytskyj, 18, 3(71), 218-220. 
Львовский национальный университет ветеринарной медицинь и биотехнологий имени С.3. Гжицкого, ул. Пекарская, 50, г. Львов, 79010, Украина

Во время течения послеродового периода, у коров встречаются случаи бактериологического заражения тканей матки, этот процесс наблюдается, более чем у 90\% животных. Если животному не было предоставлено своевременное, эффективно елечение, тогда острый воспалительный процесс переходит в хроническое заболевание. Анализируя литературные данные, мы притли к выводу, что гистероскопические исследования у коров не достаточно описано. Для постановки исследования было отобрано $5(n=5)$ коров украинской черно-белой породы в возрастеот 4 до 6 лет, у которых не проявлялась стадия возбуждения более 25 суток. Для постановки диагноза проводили гистероскопию матки у коров. Анализ полученных визуальных результатов показал, что площадь ярко-красной окраски стенок матки при субклиническом эндометрите составила - 57,6 5 5,2\%, послелеченияпрепаратом «Метродек» уменьшиласьболеечем в 7 раз и составила - 7,3 1 1,6\% ( $p<0,001) ;$ площадь наслоения экссудата на стенки матки при субклиническом эндометрите составила - 59,3 $\pm 6,5 \%$, после лечения препаратом «Метродек» в 11 раз и составила - 5,4 $\pm 1,1 \%(p<0,001)$.

Ключевые слова: корова, матка, гистероскопия, послеродовый период, эндометрит, субклинический эндометрит, бесплодие, функиия воспроизведения.

\section{Introduction}

During the postpartum period among the dairy cattle there are cases of bacteriological infection of the uterus tissues. This process occurs in over $90 \%$ of the herd. Usually it happens within three weeks after parturition, but this term is not a limit and as a result of inflammation endometritis develops, whose number reaches $20 \%$ (Šavc et al., 2016). In case when an animal wasn't provided with early effective treatment, acute inflammation becomes a chronic disease (Ball and Peters, 2004; Yablonskyy et al., 2006). The main diagnostic methods of acute inflammation in the uterus are a clinical study that involves rectal palpation, vaginal and ultrasound study, but they do not give a complete picture of the endometrium condition, whereas rectal palpation may give false positive results (Leutert et al., 2012). For diagnostics of subclinical endometritis except the abovementioned methods, cytology (Madoz et al., 2010) can also be used, but according to some authors it is an expensive method that takes too much time (Šavc et al., 2016).

Hysteroscopy of reproductive tracts became commonly used in humane medicine as a method of diagnosing infertility, polyps, hyperplasia, neoplasm, endometriosis (Stamatellos et al., 2005; Makled et al., 2014). Also, this method of diagnostics is recommended as the prior investigation in cases of cow infertility (Šavc et al., 2011). After analyzing published data, it was concluded that hysteroscopic studies aren't described enough, although it enables visual evaluation of the uterus condition and because of its informative value it may take a leading role in evaluating physiological and pathological processes occuring in the reproductive tracts, that in its turn is important in the process of establishing the diagnosis for subclinical form of inflammation of the uterus.

The aim of our study is to evaluate the effectiveness of hysteroscopy of subclinical endometritis and to provide treatment of subclinical endometritis with «Metrodek».

\section{Material and methods}

For this study $5(\mathrm{n}=5)$ cows of Ukrainian black and white breed, aged 4 to 6 years were selected, which had not shown estrus for over 25 days, or there had been no fertilization after insemination. Animals were subjected to the same conditions and feeding. Research was carried out in the Training Center «Komarnivskyy», Lviv National University of Veterinary Medicine and Biotechnologies named after S.Z. Gzhytskyi.

For establishment of the diagnosis hysteroscopy of cow uterus was performed. Endoscope Fujifilm EG-530 NW with $5.9 \mathrm{~mm}$ diameter and $1100 \mathrm{~mm}$ working length was used for manipulations. The study was carried out from early detection of subclinical endometritis to the recovery. Sacral epidural anesthesia was used when hysteroscopic studies were being carried out by $2 \mathrm{ml}$ of $2 \%$ novocaine. Endoscope was introduced into the reproductive tract of a cow by vaginal control. After of cervix had been passes through, air was pumped until it enabled carrying out of the study of uterus.

Cows with subclinical endometritis were provided with treatment by "Metrodek", which is represented by white, cylindrical sticks with the sharp end. The medication was administered via cervix into the cavity of uterus every 48 hours in a dose of one suppository per one administration. Intensity of the inflammatory process was analyzed using the program ImageJ (National Institute of Health, Bethesda, MD, USA). Statistical calculation was evaluated by the Student test in Microsoft Excel for Windows. Results are presented as the arithmetic mean value $(\mathrm{M})$ and standard deviation $( \pm \mathrm{m})$ relatively to the total visual field.

To determine intensity of the inflammatory process, we were taking into account: intensity of bright red color (setting the coverage area: HUE $=0-17$; SATURATION $=100-170 ;$ BRIGHTNESS $=195-255)$, availability of exudate (setting the coverage area: HUE $=0-255$; SATURATION $=0-140$; BRIGHTNESS $=144-255$ ), and the total visual field (setting the coverage area: HUE $=0-255$; SATURATION $=0-255$; BRIGHTNESS $=$ $76-255)$.

\section{Results and discussion}

When performing hysteroscopy of cows for establishing the diagnosis it was observed (pict. 1) that the structure of the uterus surface was picated, splendent, of red and bright red color, with uneven coloration, edematous, wrinkled and rugged, abruptly hyperemic, with blood spots of various intensity, sensitive to irritation by foreign objects (at contact with the endoscope shallow blood spots may appear). In the lumen and on the surface of the uterus feculent, viscous, mucous and pus exudate of 
gray and light gray color with admixture of blood could be observed.

Positive changes were visually noted in $80 \%$ of herd after treatment with «Metrodek»: the uterus surface was smooth, not splendent, thickenings and sometimes folds may occur, color of the uterus surface was mainly bright red equally saturated, sometimes there may appear rare blood spots, the remains of endometrium were pale pink. After the treatment the presence of mucous and pus exudates in the lumen of the uterus was barely visible. The fluid was clear, sometimes slightly feculent.
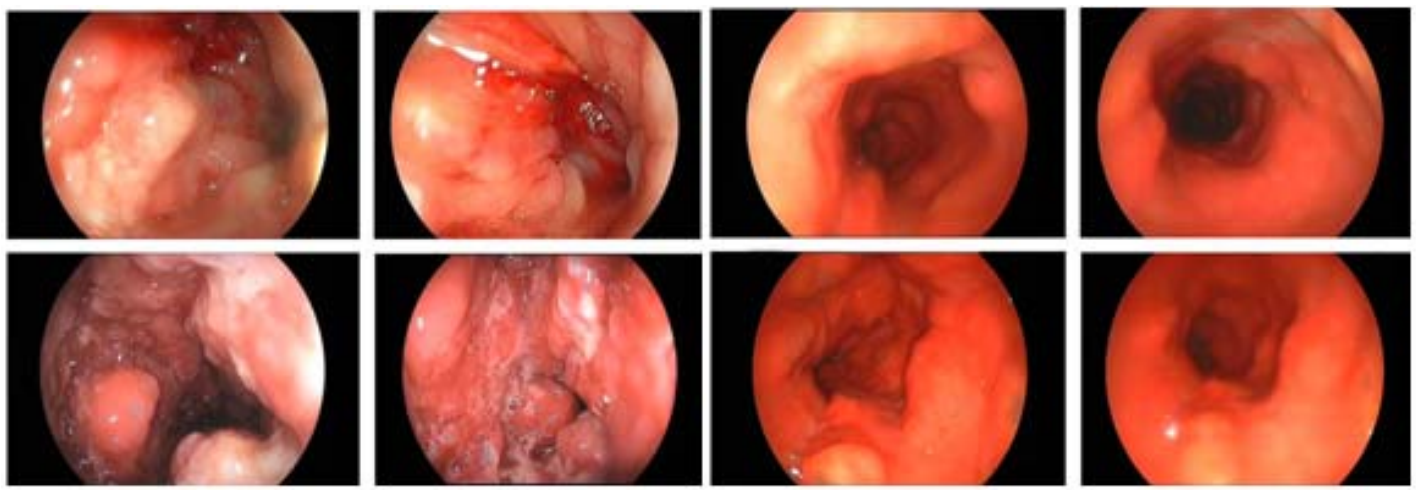

a

b
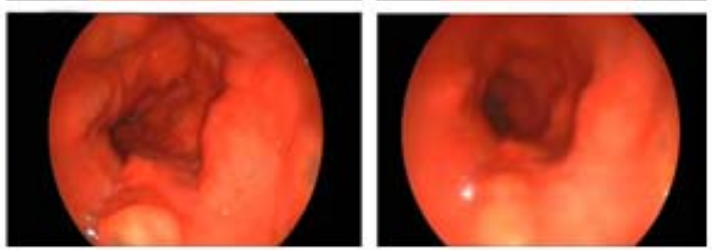

d

Pic. 1: Hysteroscopy of the cow uterus with subclinical endmometritis (a, b) and after treatment (c, d).

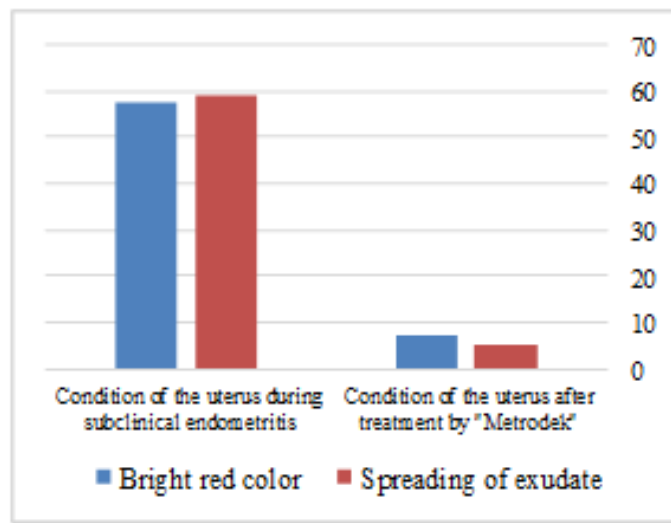

Pic.2: Intensity of the inflammatory process of the area $(\%)$ of bright red color of the endometrium and the area of exudate fusion on the uterus surface

\section{Conclusions}

1. Hysteroscopy of uterus of cows proved that this method makes it possible to quickly visually evaluate and diagnose the condition of the uterus of cows, enables to determine the intensity, dynamics, character, localization of the pathological process, and to choose the right strategy for further treatment of animals. The proposed method is effective and informative when diagnosing subclinical endometritis in practice. Manipulation carried out at hysteroscopy does not harm animals and is characterized by very low manifestations of complications.
2. Research found that treatment with "Metrodek" is a highly effective medication against subclinical endometritis of cows and efficiency of its use was about $80 \%$.

\section{References}

Šavc, M., Duane, M., O'Grady, L. (2016). Uterine disease and its effect on subsequent reproductive performance of dairy cattle: a comparison of two cow-side diagnostic methods. Theriogenology. 86(8), 1983-1988.

Ball, P.J.H., Peters, A.R. (2004). Reproduction in cattle [Third edition]. Oxford: Blackwell Publishing, 159-160.

Yablonskyy, V., Homyn, S., Kalynovskyy, H. (2006). Veterinary obstetrics, gynecology and biotechnology with the basics of Andrology. New Book, 516-517.

Leutert, C., von Krueger, X., Plöntzke, J. (2012). Evaluation of vaginoscopy for the diagnosis of clinical endometritis in dairy cows. Journal of dairy science. 95(1), 206-212.

Madoz, L., De la Sota, R., Suzuki, K. (2010). Use of hysteroscopy for the diagnosis of postpartum clinical endometritis in dairy cows. The Veterinary record. 167, 142-143.

Makled, A., Farghali, M., Shenouda, D. (2014). Role of hysteroscopy and endometrial biopsy in women with unexplained infertility. Archives of gynecology and obstetrics. 289(1), 187-192.

Stamatellos, I., Stamatopoulos, P., Rousso, D. (2005). Stamatellos I.Investigation of abnormal uterine bleeding in perimenopausal women by hysteroscopy and endometrial biopsy. Gynecological Surgery. 2(1), 51-55. Стаття надійшла до редакиії 5.10.2016 